\title{
LOWER DON AS A CONTACT ZONE OF INTERACTION OF NOMADS AND SEDENTARY POPULATION IN THE FIRST CENTURIES AD ${ }^{(*)}$
}

\author{
Vdovchenkov E. \\ Archeology and History of the Ancient World dep. South Federal Univ., Rostov-on-Don, Russia. \\ E-mail: evvdovchenkov@sfedu.ru
}

\begin{abstract}
This article describes contact zone of interaction of different cultures in the Don Region in I-III centuries $A D$. The article investigates three different ethnic and cultural groups: the nomadic tribes of the Sarmatians, the Greeks in the ancient town Tanais, Meotians on the basis of archaeological data and epigraphy. The article analyzes political, ethnic, cultural and economic aspects of interaction in the Lower Don Region. Special attention is paid to the process of sarmatisationthe transformation of the Tanais and Meotian settlements under the influence of the migration of the Sarmatians. Sarmatization has created new cultural and social phenomena. The result of the interaction has become a special cultural practices - combined the tradition of the burial rite in Tanais, extensive use of antique ceramics and other artifact by Sarmatians and Meotians.
\end{abstract}

Keywords: Lower Don, Bospor, Tanais, Sarmatians, Meotians, Contact zone

\section{Introduction}

Contact areas where different cultures and peoples meet, the object of close attention of researchers. The study of contact zones allows us to understand the peculiarities of ethnic, political and cultural interaction, to identify economic ties and social networks. Recently, the study of the past steppe zone of Eastern Europe according to archeology has significantly advanced. The data of excavations of necropolises and settlements, as well as thousands of steppe burial mounds are published. The study of the archaeological data of the eras, known to us from written sources, poses the problem of comparing the data of archeology and ancient authors. To do this, it is very promising to study the contact zones, where the comparison of data of archeology, ancient authors and epigraphy gives interesting results. Archeology allows us to obtain mass material, and written sources to interpret them correctly. Currently, it is important to study the contact zones of interaction of different cultures. This interaction gives rise to particular political, social and cultural practices. One of these zones in ancient times was the territory of the Lower Don. The Don Region in IIII centuries $\mathrm{AD}$ was inhabited by three different ethnic and cultural groups: the nomadic tribes of the Sarmatians, the Greeks in the ancient town Tanais, Meotians in the settlements on the right and left banks of the Don, fig. (1). The interaction of these peoples we can trace in three different areas: ethno-cultural, the economy and the political sphere. 


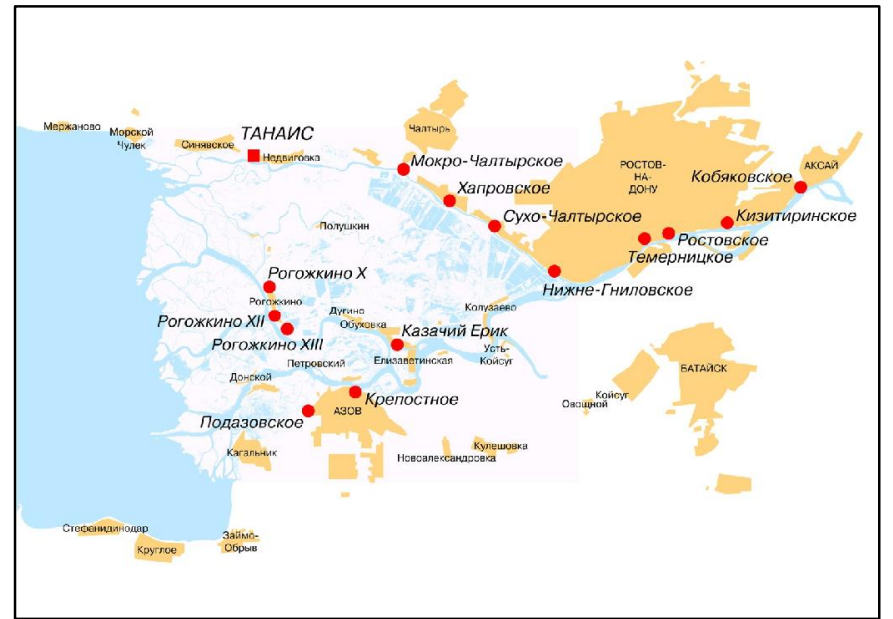

Figure (1) Shows a map of the Lower Don Region (thank Irina V. Tolochko for kindly providing me map).

\section{Political Sphere}

In the first centuries $\mathrm{AD}$ in the Don region was dominated by Sarmatian tribes [1]. Nomadic world is very volatile. Sarmatian epoch is divided into three parts Early Sarmatian, Middle Sarmatian and Late Sarmatian periods (cultures). But these periods are at least four waves of migration: the emergence of Early Sarmatian culture (II-I centuries BC); migration in the first century $\mathrm{AD}$, which led to the formation of Middle Sarmatian culture; the emergence of the Late Sarmatian culture in the Don region in the middle of the II century $\mathrm{AD}$; migration to the Don region of the Caucasus nomads in the middle of the III century AD. The concentration of barrow cemeteries with elite tombs indicates political centers of the Sarmatians [2]. The phenomenon of elite complexes of Sarmatian associated with exopolitarian (xenocracy) model of the economy. In connection with the weakness of the economic base of the nomads, Sarmatians relying on their military capability [3], looking for resources for the development in the sedentary world. The concentration of the elite complexes on the Lower don in the first centuries AD allows to conclude this region was the political center of Sarmatia. Meotian settlements played an important role in this situation. They were dependent of the nomads. A clear indication of dependence are burials of the nomadic elite in the burial of the settled population $\left(10^{\text {th }}\right.$ mound Kobyakovo necropolis, fig. (2) [4]. Households of Kobyakovo settlement existed in the steppe zone as a dependent population. Therefore, the political situation in terms of center periphery can be described as «Centre -powerful nomadic and dependent periphery-Meotians». Dynamics of development Meotian settlements in the Lower Don is also linked to the influence of the nomads. Krepostnoe settlement - the end of I century BC - II century AD; Podazovskoe - I-II century AD; Kobyakovo - I-III centuries AD; Temernitzkoe settlement - the I-III centuries ad; Nizhnegnilovskoe settlement I-III centuries AD, fig. (1)[5]. For the Tanais there are three destructive events in its history:

$\left.\mathbf{1}^{\text {st }}\right)$ the defeat of the Tanais at the turn of the eras by the Bosporan king Polemon (Strabo, Geography, XI, II, 3 ) and further recovery with partial replacement of the population.

$2^{\text {nd }}$ ) destruction in the middle of the II century AD as a result of the expansion from the steppe, after which there is the inclusion of a Sarmatian element in the composition of the urban population.

$3^{\text {rd }}$ ) destruction in the middle of the III century AD. 
These events, especially 2 and 3, are associated with exposure of the nomadic periphery. In the confrontation between the Tanais and Polemon we can also see traces of the participation of the barbarians in the political life of the Bosporus. Thus, the Sarmatians were one of the important centers of power in the steppe zone of Eastern Europe, which was opposed by the Bosporus.

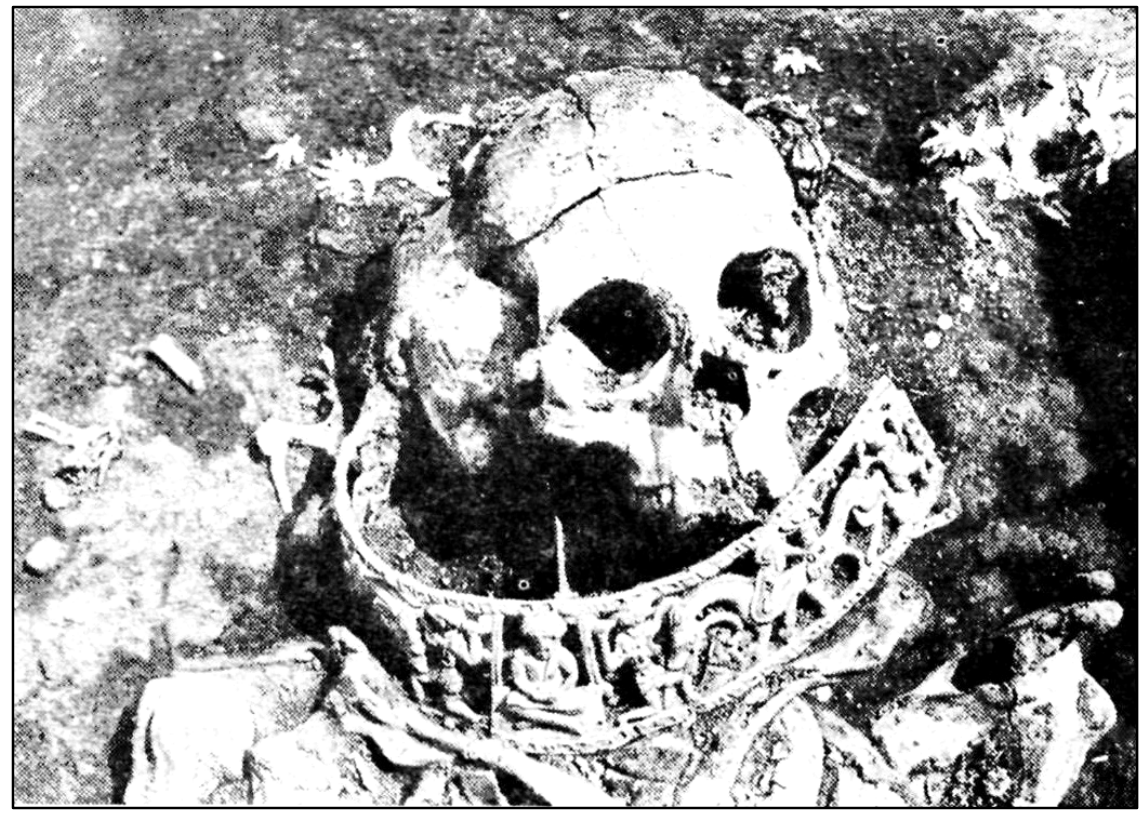

Figure (2) Shows burial in the mound 10, Kobyakov burial ground. (by Guguyev1992).

\section{Ethno-Cultural Sphere}

Meotians in the Don kept the traditions of the Kuban Meotians (catacomb burials, bowl under my head in tombs, agriculture, and ceramics). The Sarmatians in the I-III centuries are just three different groups associated with three archaeological cultures - Early Sarmatian culture, Middle Sarmatian culture and Late Sarmatian culture. The Greeks of the Tanais was also heterogeneous. The defeat of the Tanais by Polemon led to a significant shift of the population and traditions. A dominant influence in the ethno-cultural sector was provided by the Sarmatians. The first centuries of AD are the time of sarmatization. The nomads began to settle in II-III centuries, moving in Tanais and Lower Don settlements. The appearance of the Sarmatians at Tanais and Meotian settlements in the II century $\mathrm{AD}$ can be traced to the materials of the cemeteries [6], inscriptions from the Tanais, the appearance of tamgasigns, fig $_{\text {s. }}(3-a, b, c)[7]$, the use of ditches under burial ground, fig. (3-d) [8], the data of physical anthropologists. Sarmatian ceramics in in the Meotian settlements and the Tanaisin form us about the presence of the Sarmatians. These are Sarmatian incense burners, which were used in rituals, fig. (3-c). Also this is the Caucasian ceramic, which Sarmatians preferred. The Meotians and Greeks had their own ceramics, and the appearance of ceramic vessels from the Caucasus, fig. (3-e) indicates the Sarmatian presence in their settlements. I guess sarmatization of Tanais is the result as Sarmatian pressure and the special efforts of the Bosporus. The Bosphorus effectively learned the principles of the policy of Mithridates VI Eupator - «mithridatism» - the use of barbarian immigrants to strengthen their economic and military power. The sedentarisation of the Sarmatians and other barbarians had supposed their involvement in the sphere of influence of the Bosporan Kingdom. 


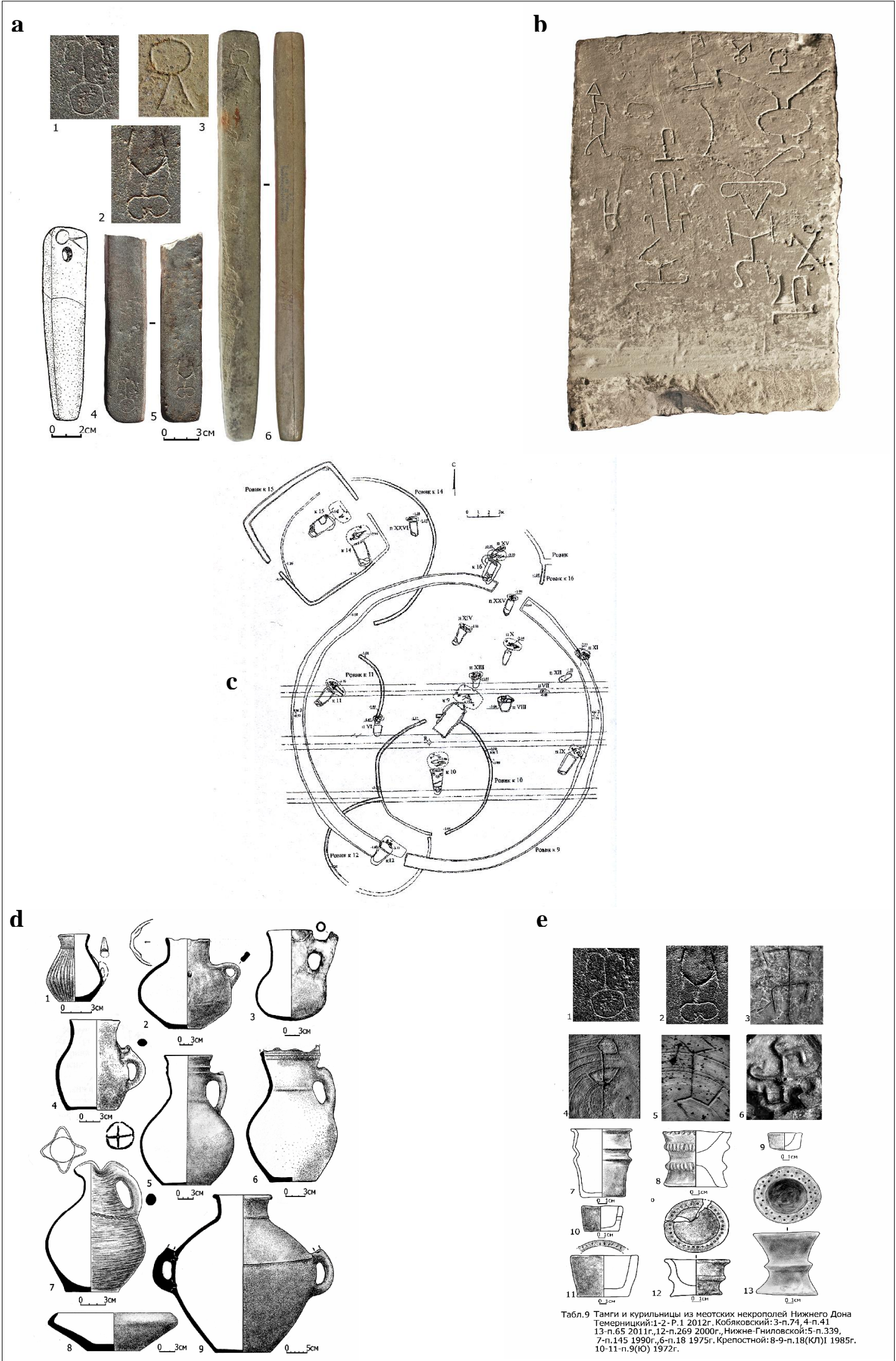

Figure (3) Shows $\underline{\text { a. }}$ Sarmatian tamgas from Tanais and Meotian's settlements, $\underline{\mathbf{b}}$. stone slab with tamgas

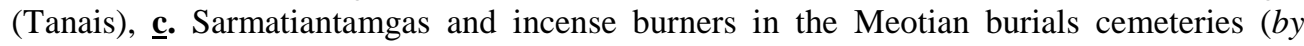
Guguyev 2017), ‥ Sarmatian tradition - ditches in Kobyakovo necropolis (by Larenok V.A.), ‥ caucasian ceramics in the Meotian necropolis -symptom of Sarmatian presence (by Guguyev 2017). 


\section{Economy}

Tanais is the largest trade and handicraft center of the Don region. It is important to note that the Tanais in III-I centuries BC did not trade with their surroundings, even after the appearance of the Early Sarmatians in the region. This is evidenced by the lack of amphora containers in the Lower Don Region during this period. This information is confirmed by Strabo (Strabo, Geography, XI.II.2). In the turn of eras we can trace a change in economic policy and increasing of the Sarmatian trade with Tanais, Meotians in the Kuban. New Meotians settlements became the important factor in the Lower Don since turn of the eras. Meotian settlements specialized in agriculture, cattle breeding and fisheries. We don't have a lot of information about the development of the craft at the Don Meotians society. There is a point of view about Meotian settlements as a Chora of Tanais. However, this view can be challenged. Close economic ties Don Meotians and the Tanais is an indisputable fact. But it is unclear how Meotians depended on the Tanais and the Bosporan Kingdom. They probably depended more of the Sarmatians. The economy of the Sarmatians, as typical nomads, characterized by extensive nomadic pastoralism. The role of the Sarmatians in the region's economy was that they were the suppliers of cattle and slaves, and customers (at least, Handicrafts and millet). The Sarmatian subsidence led to the changing nature of their occupations. Possible cause of sedentarization the drought in the Don steppes, and, consequently, the deterioration in the terms of nomadism. In the settlements the Sarmatians were engaged in trade and agriculture. Cultural interaction in the Don region led to the emergence of special practices. Material culture and burial rites of the population of Lower Don show a mixture of different elements. This borrowing of Greek traditions (burial of children in amphoras at Meotian necropolis), the mixed nature of the burial rite in Tanais (Bosporan funerary wreaths, the Obol of Charon combined with elements of Sarmatian burial rite), extensive use of antique ceramics and other artifact. Meotians and the Greeks were under the influence of Sarmatian warfare. Sarmatization has created a new cultural and social phenomenon. The emergence of a large number of Sarmatian settlers on the territory of the Tanais II-III cent. AD causes the demand for special practice of acculturation. The cult of the Most High God in the Bosporus traced in Tanais and Gorgippia in the I-III centuries [9]. The cult of the Most High God was central to civic life of Tanais. The emergence of a large number of sarmatian immigrants in Tanais in II-III cent. AD is the need for their acculturation. Cult of the Most High God - the way they are embedded in the religious and political systems of the Bosporus. Distribution of the new cult was connected with the needs of the Bosporan kingdom in the new ideology for military groups of barbarians. The end of the system, where Sarmatian groups served as the political center, based on the economic potential of the Meotian settlements, and interacted with the Tanais, is associated with the arrival of nomads from the Caucasus to the Don region in the middle of the III century AD. The second phase of the Late Sarmatian culture (mid. III - second half of IV cent. AD) led to great changes in the political system of the steppe zone of Europe. We can see the death of the Lower Don settlements and the decline contact zone of interaction. Lower Don steppe lost status of a key political center in Sarmatia. Thus, we see that archaeology gives us the opportunity to reconstruct the economic, political and ethno-cultural life of the region. The study of contact zones allows us to see not only the differences of the cultures of the Greeks, Sarmatians and Meotians, but their interaction and the processes of sarmatisation of sedentary centers. Currently, archaeological data are a 
reliable foundation for the study of the ancient history of Eastern Europe. The experience of studying these archaeological cultures shows us that ancient societies in the contact zones formed a special space of dialogue of cultures and different social practices. The mutual influence of cultures generated specific features that distinguish the Lower Don area from other Black sea regions.

\section{Conclusion.}

Thus, we see that archaeology gives us the opportunity to reconstruct the economic, political and ethno-cultural life of the region. The study of contact zones allows us to see not only the differences of the cultures of the Greeks, Sarmatians and Meotians, but their interaction and the processes of sarmatisation of sedentary centers. Currently, archaeological data are a reliable foundation for the study of the ancient history of Eastern Europe. The experience of studying these archaeological cultures shows us that ancient societies in the contact zones formed a special space of dialogue of cultures and different social practices. The mutual influence of cultures generated specific features that distinguish the Lower Don area from other Black sea regions.

\section{References}

[1] Harmatta, J., (1970). Studies in the history and language of Sarmatians: Acta Universitatis de Attila Jozsef nominate, Acta Antiqua et Archaeologica, Tomus XIII, Szeged.

[2] Raev, B., (1986). Roman imports in the lower Don basin. (BAR Intern. Ser., 278.): Reeder, E., Oxford

[3] Mielczarek, M., (1993). Cataphracti and clibanarii, studies of the heavy Armoured cavalry of the ancient world, Łódź, Oficynanaukowa MS.

[4] Гугуев, В., (1992). Kobakovsky mound (To the question of Eastern influences on the culture of the Sarmatians in the first century AD-beginning of the II century AD). Becтникдревнейистории, Vol. 4, pp: 116-129

[5] Шелов, Д., (1972). Шелов, Д. Б. Танаис и Нижний Дон в III-I вв. До н. э. (Tanais and Lower Don in the first centuries $A D$ ), Nauka, Moscow.
[6] Гугуев, В., (2017). The structure of the ritual of necropolis of don meots (on the role of Sarmatians in the formation of the population of settlements). ВестникТанаиса, Vol. 4, pp: 128-148.

[7] Yatsenko, S., (2010). Marks of the ancient and early medieval Iranianspeaking Peoples of Iran, Eastern Europe, Transoxiana and South Siberia, in: Pim, J., Yatsenko, S. \& Perrin, O. (eds.) Traditional Marking Systems: A Preliminary Survey, Dunkling Books, London, pp: 133-154.

[8] Ларенок, B., (2016). Funerary complexes with rovics (Kobyakovsky settlement necropolis). Archaeoastronomy and Ancient Technologies, Vol. 4 (2), pp: 1-26.

[9] Ustinova, Yu., (1999). The supreme gods of the Bosporian Kingdom, Celestial Aphrodite and the Most High God, Brill, Leiden.

$\left.{ }^{(*}\right)$ The research was carried out within the framework of the grant of the Russian Foundation for Basic Research no. 17-06-00464 "Historical dynamics of political institutions: from local potestarnosti to the global World System". 